\title{
Men's health care: construction and validation of a tool for nursing consultation
}

\author{
Atenção à saúde do homem: construção e validação de instrumento para consulta de enfermagem \\ Atención de salud del hombre: construcción y validación de instrumento para consulta de enfermería
}

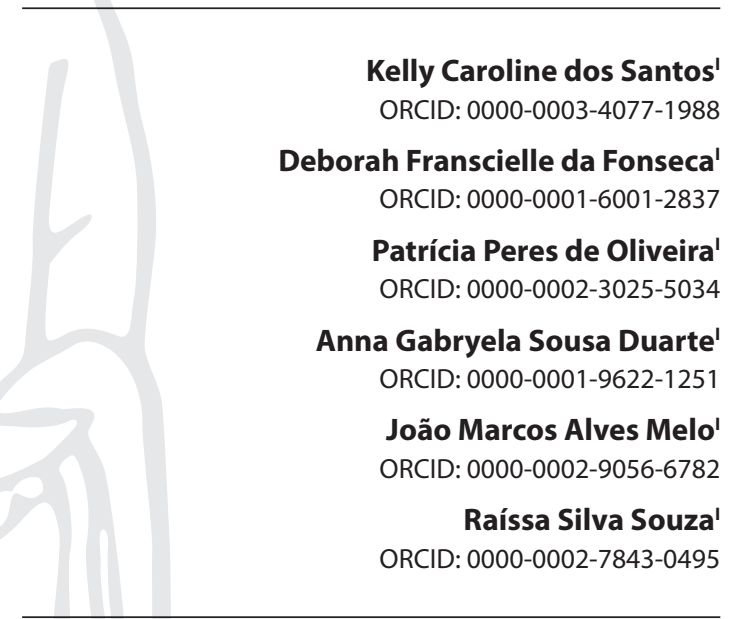

'Universidade Federal de São João del-Rei. Divinópolis, Minas Gerais, Brazil.

How to cite this article:

Santos KC, Fonseca DF, Oliveira PP, Duarte AGS, Melo JMA, Souza RS. Men's health care: construction and validation of a tool for nursing consultation.

Rev Bras Enferm. 2020;73(3):e20190013. doi: http://dx.doi.org/10.1590/0034-7167-2019-0013

\section{Corresponding author:}

Deborah Franscielle da Fonseca

E-mail: deborahfonseca@hotmail.com

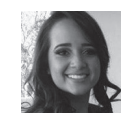

EDITOR IN CHIEF: Antonio José de Almeida Filho ASSOCIATE EDITOR: Hugo Fernandes

Submission: 02-19-2019

Approval: 07-03-2019

\section{ABSTRACT}

Objectives: to elaborate and validate a data collection tool for nursing consultation with men in the context of Primary Health Care. Method: a methodological study developed in four stages. The first one consisted in tool elaboration, using databases and the Dorothea Orem's theoretical model. In the second and third stages, content validation and tool appearance by 23 nurse judges took place. The Concordance Index was used for assessment. In the fourth stage, a pilot test was carried out with 20 men using Primary Health Care. Results: of the 145 indicators prepared, organized and submitted to validation process, items with the Concordance Index $<0.80$ were excluded. The final tool consisted of 156 items. An overall 0.88 Concordance Index calculation was obtained. Conclusions: the final tool presented content validity for data collection with men in Primary Health Care. Descriptors: Office Nursing; Men's Health; Nursing Theory; Validation Studies; Public Health.

\section{RESUMO}

Objetivos: elaborar e validar um instrumento de coleta de dados para consulta de enfermagem junto ao homem no contexto da Atenção Primária à Saúde. Métodos: estudo metodológico, desenvolvido em quatro etapas. A primeira consistiu na elaboração do instrumento, utilizando-se bases de dados e o modelo teórico de Dorothea Orem. Na segunda e terceira etapas, ocorreu a validação de conteúdo e aparência do instrumento por 23 juízes enfermeiros. Para avaliação, foi utilizado o Índice de Concordância. Na quarta etapa, foi realizado o teste piloto com 20 homens usuários da Atenção Primária à Saúde. Resultados: dos 145 indicadores elaborados, organizados e submetidos ao processo de validação, foram excluídos os itens com Índice de Concordância menor que 0,80. O instrumento final foi composto por 156 itens. Obteve-se o cálculo de Índice de Concordância global de 0,88. Conclusões: o instrumento final apresentou validade de conteúdo para a coleta de dados junto a homens no contexto da Atenção Primária à Saúde.

Descritores: Enfermagem no Consultório; Saúde do Homem; Teoria de Enfermagem; Estudos de Validação; Saúde Pública.

\section{RESUMEN}

Objetivos: elaborar y validar un instrumento de recolección de datos para consultas de enfermería con hombres en el contexto de la Atención Primaria de Salud. Métodos: estudio metodológico desarrollado en cuatro etapas. El primero consistió en la elaboración del instrumento, utilizando las bases de datos y el modelo teórico de Dorothea Orem. En la segunda y tercera etapas, se llevó a cabo la validación del contenido y la apariencia del instrumento por 23 enfermeras jueces. El índice de concordancia se utilizó para la evaluación. En la cuarta etapa, se llevó a cabo una prueba piloto con 20 hombres utilizando la Atención Primaria de Salud. Resultados: de los 145 indicadores preparados, organizados y presentados al proceso de validación, se excluyeron los ítems con índice de concordancia $<0,80$. El instrumento final consistió en 156 ítems. Se obtuvo un cálculo global de índice de concordancia de 0,88 . Conclusiones: el instrumento final presentó la validez de contenido para la recopilación de datos con hombres en el contexto de la Atención Primaria de Salud. Descriptores: Enfermería de Consulta; Salud del Hombre; Teoría de Enfermería; Estudios de Validación; Salud Pública. 


\section{INTRODUCTION}

Since the Family Health Program (FHP) deployment in 1994, men's reduced demand for services offered in Primary Health Care $(\mathrm{PHC})$ is still a problem ${ }^{(1)}$. This difficulty may be related to the Brazilian culture that cultivates male superiority, influenced by social and gender paradigms, since caring is not a common practice for men, a fact that may hinder health promotion ${ }^{(2)}$.

Brazilian data reveal high rates of morbidity and mortality among men, and out of every three adults who die in Brazil, two are male, and such deaths could have been avoided if there was greater demand from men for health services regarding health promotion and disease prevention actions ${ }^{(3)}$.

In order to strengthen actions and services in men's health care networks, the Ministry of Health (MoH) in 2009 established the Brazilian National Policy for Comprehensive Care for Men's Health (PNAISH - Política Nacional de Atenção Integral à Saúde do Homem $)^{(4)}$. PNAISH, the Brazilian National Primary Care Policy (PNAB - Política Nacional de Atenção Básica) and the Family Health Strategy (FHS) seek to propose new strategies, in addition to optimizing and organizing health services for promotion, protection, prevention and rehabilitation. They are based on health humanization and consider man uniqueness ${ }^{(1,4-5)}$.

In the context of PHC practice, weaknesses and scarcity of health actions directed specifically at men are observed. Thus, it is essential to sensitize the professionals who serve them, encouraging them to understand and accept this demand, in order to establish bond, educate and develop health promotion and disease prevention actions in a systematic and individual-centered way ${ }^{(3,5)}$.

Men's health nursing care in PHC comprises a series of systematic actions encompassing user access, embracement, and reception; nursing consultation with progressively comprehensive holistic assessment of the health situation of the individual, family and community; definition of nursing diagnoses; intervention establishment; nursing care assessment and notes; referrals to multidisciplinary consultations or specialized service ${ }^{(5-6)}$.

Regarding the nursing consultation, it is a private nurse activity, performed at all levels of public or private health care, including men's health in the context of PHC. Its operationalization occurs through the Nursing Process (NP). NP is considered as the main theoretical-methodological model that directs nurses' actions in their professional practice to identify health / disease situations, establish nursing measures that contribute to health promotion, besides disease prevention and health recovery of the individual, family, and community ${ }^{(6-9)}$.

Regarding NP, nursing consultation comprises interrelated, interdependent and recurrent actions, such as data collection, nursing diagnosis, nursing planning, establishment and assessment. For data collection, recording tools use is suggested in order to make it systematized and sufficient to support the other steps involving $N P^{(8-9)}$.

The first stage of NP, investigation, is the identification of phenomena presented by the clientele, being pointed as a fundamental foundation for the Systematization of Nursing Care (SNC) development. The objectivity, reliability, and comprehensiveness of how data are collected in this process will influence care planning ${ }^{(8)}$, since they allow the identification of nursing diagnoses that will support a care plan ${ }^{(7)}$.
It is evident that the use of nursing theories with theoretical support for NP development is provided for in Resolution 358 of 2009 of the Nursing Federal Council (COFEN - Conselho Federal de Enfermagem). This occurs in order to guide this process from data collection, diagnose establishment and nursing intervention planning to result assessment ${ }^{(9)}$.

Although several conceptual models and nursing theories have been developed in the last decades, this study is based on the Self-Care Theory (SCT). SCT was developed by Dorothea Elizabeth Orem, as it is believed that men's nursing care in the context of PHC must include the possibility of negotiation, respect for autonomy and individuality of the male gender ${ }^{(3)}$.

SCT is one of three theories that make up the Self-Care Deficit Theory ${ }^{(10-11)}$. In PHC, where prevention and self-care are paramount, this is a widely used theory ${ }^{(12)}$. SCT starts from the hypothesis that individuals are able to take care of themselves and, in episodes where there is a deficit, they are encouraged to increase self-care practices in order to provide personal well-being ${ }^{(11-12)}$.

SCT indicates specific requirements that must be exercised by individuals: universal ones, such as food intake, prevention of dangers to human life, balance between loneliness and social interaction; developmental ones, encompassing facts and processes that negatively influence healthy individuation; and those of health deviations, which can hinder the self-care aptitude of individuals, being confirmed when there is presence of diseases. When these requirements are not met and self-care deficits are identified, the determinant data for the development of Systems Theory in Nursing are constituted ${ }^{(12)}$.

Considering the overview presented and, when nursing consultations were held with individuals in a family health unit in the countryside of Minas Gerais State, it has been verified the absence of a tool used by nurses and nursing students focusing on male users that would allow patient comprehensive approach and nursing phenomenon identification.

The use of a specific data collection tool can facilitate the understanding of these individuals' responses to their disability, allowing the nursing professional to individualize and direct care. These aspects are important for care humanization and SNC establishment, which has already been advocated by public health policies and COFEN ${ }^{(6,9)}$.

Given this concern, understanding the importance of nursing consultation for the individual and community's health was one of the motivations for this study. Moreover, there was a shortage in the literature of specific tools for collecting data from male PHC users that could be used in the investigation phase and subsidize NP application.

\section{OBJECTIVES}

To elaborate and validate a data collection tool for nursing consultation with men in the context of PHC.

\section{METHODS}

\section{Ethical aspects}

The study was approved by the Research Ethics Committee of Universidade Federal de São João del-Rei. Participants involved 
in tool validation and pilot testing signed the Free and Informed Consent Term. The ethical precepts of research with human beings, based on Resolution 466/2012 of the Brazilian National Health Board (Conselho Nacional de Saúde), were respected ${ }^{(13)}$.

\section{Study design}

It is a methodological study, developed in four stages. In the first stage, empirical indicators were identified through scientific literature integrative review, which supported data collection tool elaboration. In the second stage, there was content validation and appearance by nurse judges. In the third stage, after tool analysis and changes, according to judges recommendations, the final version was prepared. The fourth step corresponded to the pilot test of this tool application with men using PHC.

\section{Place of study, period, inclusion and exclusion criteria}

The study setting was the PHC of a municipality of Minas Gerais. Local health care is linked to the Brazilian Unified Health System (SUS - Sistema Único de Saúde). Among services that make up the municipal healthcare network, there are 32 Basic Health Units (BHU) with Family Health teams and 11 traditional BHUs.

Elaboration, application, and assessment of the data collection tool for nursing consultation for men's health occurred was held from April to November 2018.

To validate the tool, the following inclusion criteria for judges were considered: being a resident nurse or preceptor nurse in the study setting. Those who were on vacation or any type of leave during the collection period were excluded. These criteria were met, and a total of 23 nurses were obtained, being 12 preceptors and 11 resident nurses.

For the tool pilot test, adult men, between 20 and 59 years old, registered in one of the BHU with Family Health team of the study setting (service where the first author performed the practical activities of a Residency Program in Primary Care/Family Health) were included. Those with alterations in orientation, memory, and attention were excluded (applying the Mini-Mental State Examination MMSE)(14).

To stipulate the pilot test sample, a calculation was performed considering the total number of patients registered in this $\mathrm{BHU}$, 95\% confidence interval and 5\% sampling error, resulting in 198 service users. Given that this is a pilot study and, to this end, a percentage of approximately $10 \%$ is suggested ${ }^{(15)}, 20$ male users selected for convenience participated.

\section{Work steps}

The research was outlined, following the steps below:

In the first stage, empirical indicators for the data collection tool composition were identified through a scientific literature integrative review. A search was performed on the Medical Literature Analysis and Retrieval System Online, Latin American \& Caribbean Literature on Health Sciences and Nursing Database (BDENF - Base de Dados em Enfermagem). This search was performed by combining the MeSH to the research mnemonic: (Men's Health [Mesh]) AND (Nursing [Mesh] OR Nursing Theory [Mesh]). Database search generated 29 papers, after reading titles and abstracts, and removing duplicates. Therefore, eight studies remained, which were included in the main analysis.

From this, the first empirical indicators of the composition of the tool emerged. Identification items have been defined (name, municipality identification number, sexual orientation, date of birth, age, marital status, address, place of birth, education, occupation, monthly household income); other items according to Orem's SCT (Universal requirements: health promotion, nutrition and hydration, eliminations, activity and rest, self-perception, roles and relationships, sexuality, life principles, safety and protection, and comfort; Developmental requirements; Health deviations: health and disease process, nutrition and hydration; elimination and exchange, activity and rest, perception and cognition, self-perception, roles and relationships, sexuality, life principles, safety, protection, and comfort; Self-Care Deficit and Nursing System). Thus, the tool was structured by categorizing the empirical indicators related to men's health according to Orem ${ }^{(10)}$.

In the second stage, the tool's first version was validated with nurse judges that was characterized from a structured questionnaire. After validating tool content and appearance, empirical indicators were validated. To assist in this step, a column attached to the tool was used to classify empirical indicators as 'not relevant' and 'relevant', insert suggestions and justifications for the removal or inclusion of empirical indicators. Empirical indicators classified as relevant received weight one and not relevant zero weight. Empirical indicators that reached Concordance Index $(\mathrm{Cl})$ (16) equal to or greater than 0.80 were validated, and empirical indicators with $\mathrm{Cl}$ below 0.80 were not considered for inclusion.

Suggestions for inclusion of items were assessed and introduced depending on the $\mathrm{Cl}$ and relevance to the study regarding relevance, objectivity, simplicity, clarity, relevance, accuracy, updating, vocabulary, typicality, credibility, conceptual breadth of the item, and balance, criteria set by Pasquali ${ }^{(16)}$.

In the third stage, there was data collection tool format in its final version. It was again presented to judges to reaffirm and endorse the changes made, and then to format the final version of the tool. All judges approved as a version to be applied to male PHC users of the municipality.

After validation with nurse judges, in the fourth step, the tool was applied to the target audience by an interviewer (first author) who followed a Standard Operating Procedure elaborated by the authors, containing conceptual and operational definitions. These consultations were held in a private room of the $\mathrm{BHU}$, where the interviewer was resident in nursing or at the home of this male $\mathrm{BHU}$ user. It was recorded the tool start and end time of data collection, which allowed measurement of the time stipulated for application. The average time for tool application was 30 minutes.

\section{Data analysis}

Data were compiled using Excel ${ }^{\circ}$ software, with analysis in the Statistical Package for Social Sciences (SPSS), version 21. Cl of the items considered relevant was calculated, and a $\mathrm{Cl}$ equal to or higher than 0.80 was adopted. that is, the equivalent of $80 \%$ agreement among PHC nurses, which is considered optimal (17). Items that did not reach this value were discarded. Moreover, all suggestions from the judges were considered. Cl was calculated 
by summing the number of answers marked by " 1 " by study participants, divided by the total number of answers.

Data regarding pilot test application were analyzed by frequency and percentage distribution.

\section{RESULTS}

Preparation, structuring of the tool for data collection and registration, and content validation by nurses working in $\mathrm{PHC}$ were elaborated. Twenty-three nurses participated to assess the tool, 12 of which were preceptors of a residency program and 11 were nursing residents. Of these, most were female ( $83 \%$ ), aged between 20 and 30 years (47.8\%), average of 29.7 years, $60.8 \%$ had one to 10 years of graduation, 52 , $1 \%$ reported having completed graduate school. Of these, two nurses also had a master's degree. Regarding the time of work in PHC, most worked for over two years (52.2\%). Eleven (47.8\%) participants had experience in tool validation and all (100.0\%) had knowledge and practice in nursing consultation, SNC and nursing diagnoses.

The tool for collecting and recording data for men's nursing consultation in the context of PHC, based on Dorothea Orem's framework, contains a header with identifying data. It was then divided into self-care requirements (universal, human development, and health deviation), self-care deficit and nursing systems. To group the information that makes up the tool, NANDA domains were chosen ${ }^{(18)}$. The domains were allocated within Orem's self-care requirements, in order to facilitate the survey of nursing diagnoses afterwards.

In the first version of the tool, 145 empirical indicators were presented regarding identification data, universal requirements (health promotion, nutrition and hydration, eliminations, activity and rest, self-perception, roles and relationships, sexuality, life principles, safety and protection, and comfort), developmental requirements, health deviations (health and disease process, nutrition and hydration; elimination and exchange, activity and rest, perception and cognition, self-perception, roles and relationships, sexuality, life principles, safety and protection and comfort), Self-Care Deficit and Nursing System. One hundred fifty-seven (98.0\%) indicators reached $\mathrm{Cl}$ equal to or above 0.80 and three (2.0\%) empirical indicators were not validated, as they presented $\mathrm{Cl}$ below 0.80 and belonged to the item health deviations (roles and relationships and life principles). Thus, the tool in the version after validation by nurse judges had 155 empirical indicators.

In the fundamental requirements, elimination and exchange, self-perception, roles and relationships, life principles, health deviations, health-disease process, elimination and exchange, self-perception, coping, and self-care deficit reached $1.0 \mathrm{Cl}$, that is, $100 \%$ agreement among judges.
The readjustments suggested in the tool included items on: a) address, identification code and sexual option; b) Universal Requirements: Inserted the item "Do you think smoking is bad for you or disturbs you?"; nutrition and hydration - placed the food recall, asks if the individual consumes ultra-processed products and if there was loss or weight gain in the last year; activity and rest, inserted "hours of sleep per night"; sexuality, number of partners in the last year and if the person has ever had sexually transmitted infections (STIs).

Among the excluded items, we highlight data on: a) Universal requirements: health promotion - small picture, which contained the description of all vaccines, with two specific questions about alcoholism removed. Security and protection were changed places: monthly family income and number of people living with this income were for data identification.

Developmental requirements included items on accidents with venomous animals or automobiles. In health deviations, pain site was included in comfort.

In the tool's pilot test phase with the target population $(n=20)$, the average age was 51.2 years, most participants declared themselves married or in a stable union ( $n=12 ; 60.0 \%)$, Catholic religion $(n=14 ; 70 ; 0 \%)$ and smoker $(n=11 ; 55.0 \%)$. Nursing consultation was held at the $\mathrm{BHU}$ in a private room with $80.0 \%$ of men.

In this process, it was found in the universal requirements, in the field of health promotion, the need to include in case of incomplete vaccination, which are they, since most had delayed vaccines $(n=12$; $60.0 \%$ ). In self-perception, it was necessary to exclude the question "how do you perceive your life today?" because everyone answered the same question as the previous question "are you satisfied with your life?". It was necessary to include a place to write the nurse's impressions, observations or complications during data collection.

It was found that the average time for tool application the researcher was 30 minutes, and the first interview lasted 40 minutes, and the twentieth, 14 minutes. After the pilot test, the researcher who applied the tool was asked about possible comprehension difficulties by men. The interviewer who applied the tool considered it appropriate, with no need for adjustments at this time. Validated empirical indicators are presented in the tool, final version according to Chart 1.

The tool, initially made with 145 empirical indicators, was modified after validation with the judges (155 items in this stage) and the pilot test with the target population, finalizing the format with 156 indicators and a 0.99 overall $\mathrm{Cl}$.

As suggested by the participating nurses, a support guide was developed to guide the use of the data collection tool by nurses or nursing students. Items not previously mentioned remained in the tool. Others were modified regarding the categories, and the tool was formatted.

Chart 1 - Data collection tool for nursing consultation for men's health care in the context of PHC, final version, Minas Gerais, Brazil, 2018

Data collection tool for nursing consultation for men's health care, based on Dorothea Orem's Self-Care Theory

1. Identification data:

Name:

Date of birth: _ _ _ Age: _ marital status:

SIS (Brazilian Integrated Health System - Sistema Integrado de Saúde) number:

Sexual orientation: () Heterosexual () Homosexual () Bisexual

Address:_Origin

If retired, what profession did you have before retirement?

How many people live with this income?

To be continued 


\section{Universal requirements:}

\section{1-Health promotion}

What is your perception of your health?

What have you been doing to improve your health?

If not, which one?

Smoking

Smoker? ( ) No ( ) Yes. If so, number of cigarettes/day: ____ How long have you been smoking:

Have you tried to decrease or quit? ( ) No ( ) Yes. If so, for how long?

Alcoholism

Alcoholic () No () Yes. If so, when was the last time you had drunk and in what quantity?

Over the past 30 days, how many days did you drink alcohol? $\quad$ *Has anyone ever said you have a drinking problem? () No () Yes. *Have you

ever felt that you should reduce the amount of drink or stop drinking? ( ) No ( ) Yes. *Do people upset you because they criticize your drinking?

( ) No ( ) Yes. *Have you ever felt guilty about the way you usually drink? ( ) No ( ) Yes. *Do you drink in the morning? (to wake up?) ( ) No ( ) Yes.

If the individual answers "yes" to two or more questions with an asterisk $(*$ ), you should suspect alcohol abuse and conduct a fuller substance abuse assessment.

If not:

Ask the reason for this ( ) psychosocial, ( ) health, ( ) legal decision. Have you had any treatment for alcoholism? ( ) No ( ) Yes. Are you involved in recovery activities? ( ) No ( ) Yes. Is there any family history of drinking problems? ( ) No ( ) Yes. Illicit drug use? ( ) No ( ) Yes. If so, type of substance: Time of use: Are you involved in recovery activities or wish to cease use? ( ) No ( ) Yes

\section{2- Nutrition and hydration}

What foods are present in your diet (food recall)?

day? What is the interval between meals? _ How much fluid do you drink per day? Do you have any food preferences?

Has there been weight loss or gain in the last year? ( ) No ( ) Yes. Do you use ultra-processed foods? ( ) No ( ) Yes.

If so, which ones?

\section{3- Eliminations}

Urinary elimination- Frequency:_Color:__ Smell:__Pain? () No ( ) Yes. Incontinence? ( ) No ()Yes

Fecal elimiation - Frequency:___ Color:___ Pmell:___ Pain? () No ( ) Yes. Incontinence? ( ) No ( ) Yes. Constipation? () No ( ) Yes.

Diarrhea? ( ) No ( ) Yes

\section{4- Activity and rest}

Do you perform any physical activity? ( ) Yes, which one (s)?

No, why?

Do you wake up at night? ( ) No ( ) Yes. If so, how many times?

Frequency? () ()

Do you have trouble initiating and maintaining sleep?

When you wake up in the morning, do you feel rested? ( ) No ( ) Yes.

\subsection{Self-Perception}

Are you satisfied with your life? ( ) No ( ) Yes. Would you like to change something in your life? () No ( ) Yes.

\section{6- Roles and relationships}

How is your relationship with your family?

What is your social support network?

And with your friends and co-workers?

Does any family situation bother you or cause discomfort? ( ) No ( ) Yes.

\section{7-Sexuality}

Do you have an active sex life? ( ) No ( ) Yes. Number of sexual partners in the last year:

Have you had any IST? () No ( ) Yes. If so, which one (s)?

( ) Yes. Do you have difficulty having sex? ( ) No ( ) Yes. If so, which one and how long?

Do you use condom? ( ) No ( ) Yes. Did you get treatment? ( ) Not

\section{8- Life principles}

Do you have a religious belief? ( ) No ( ) Yes. Do you seek support in your faith during difficult times? ( ) No ( ) Yes.

What does spirituality or religion mean to you in your daily life?

What are your sources of hope?

Do you express a desire to increase hope? ( ) No ( ) Yes

\section{9- Safety and protection}

Skin integrity: ( ) preserved ( ) impaired, place:

Temperature: __ ${ }^{\circ} \mathrm{C} ; \mathrm{RR}$ : _ _ irpm. Fasting capillary blood glucose:

Blood pressure: $\mathrm{mmHg} ; \mathrm{HR}$ : BMI:

\subsection{Comfort}

House: () own () rented; ( ) masonry () wood () other. How many rooms?__Number of people living in the residence?_Basic Sanitation: Treated Water: ( ) No ( ) Yes. Plumbing: ( ) No ( ) Yes. Can you perform self-care (bathing, brushing your teeth, changing clothes) alone? ( ) No ( ) Yes.

\section{Developmental requirements}

Childhood/adolescent diseases or trauma:

Severe illness or chronic degenerative diseases/disease sequel:

If so, reason/place/duration/when?

Surgeries? () No ( ) Yes, If so, type/place/reason/when?

Have you ever had an accident with venomous animals? ( ) No ( ) Yes. If so, which one:

Have you ever had an accident at work? ( ) No ( ) Yes. If so, which one (s):

Have you had any kind of car accident? ( ) No ( ) Yes. If so, which one (s): 


\section{Health deviations}

\section{1- Health-disease process}

Current complain?

Do you have any disease? ( ) No ( ) Yes, which one (s)?

Are you taking any medicine/ tea or medicinal plant? ( ) No ( ) Yes. If so, describe them: 100

\begin{tabular}{|l|l|l|l|l|l|}
\hline NAME & DOSE & ROUTE OF ADM. & TIME & TIME OF USE & WHO INDICATED \\
\hline & & & & \\
\hline & & & & & \\
\hline
\end{tabular}

Do you have any kind of allergy? ( ) No ( ) Yes, which one (s)?

Have you undergone examinations recently? ( ) No ( ) Yes, which one (s)?

\section{2- Nutrition and hydration}

Oral cavity: ( ) Healthy ( ) Injured. If so, place (s)

( ) complete ( ) incomplete ( ) dental prosthesis. Hygiene: ( ) preserved () precarious. Lips: ( ) Hydrated ( ) Dry

\section{3- Eliminations and exchange}

Skin and mucous membranes: ( ) Hypocolored ( ) Ichteric ( ) Edema in upper limb ( ) Edema in lower limb. Cardiovascular: 2N BNRNF ( ) Yes ( ) No / Pulse: ( ) Full ( ) Fine ( ) Rhythmic ( ) Arrhythmic. Pulmonary apparatus: Decreased vesicular murmurs: ( ) Yes ( ) No; Adventitious noises? ( ) No ( )

Yes. If so, place (s): Cough? ( ) Drought ( ) productive. Abdomen: ( ) Globous ( ) Excavated ( ) Distended ( ) Tense ( ) Tympanic ( ) Massive ( ) Painful. Intestinal Noises: ( ) hypoactive ( ) active ( ) hyperactive

\section{4- Activity and rest}

Do you have any cardiovascular changes? ( ) No ( ) Yes. If so, which one (s)?

If so, which one (s)? Of mobility? ( ) No ( ) Yes. If so, which one (s)?

Musculoskeletal? ( ) No ( ) Yes.

\section{5- Perception and cognition}

Eyes: Decreased visual acuity? () No () Yes; ( ) right eye () left eye. Do you use glasses/contact lenses?

( ) No ( ) Yes. Ear: Decreased hearing acuity? ( ) No ( ) Yes; ( ) dirt ( ) secretion ( ) hyperemia. Nose: ( ) Deviation of septum ( ) Dirt ( ) Secretions.

Speech: Do you have changes in speech? ( ) No ( ) Yes. If so, which one (s)?

Tact: ( ) No changes ( ) Decreased pain perception ( ) Decreased thermal perception ( ) Tactile perception decreased. Risk for falls? ( ) No ( ) Yes

\section{6- Self-perception}

Perceived change in mood/feelings over the past year: ( ) is optimistic ( ) refers to discouragement ( ) sadness almost everyday

() recurring negative feelings ( ) constant fear ( ) frequent irritability ( ) dull affect ( ) others

\section{7- Roles and relationships}

Social interaction: ( ) relates to their peers in a balanced way ( ) does not make friends with facilities () prefers to be alone

( ) does not adapt easily to new places or situations.

\section{8- Sexuality}

Report: ( ) Absence of sexual interest ( ) Erectile dysfunction ( ) Premature ejaculation ( ) Sexual stimulant use, frequency of use:

\section{9- Life principles}

Spiritual Support: do you realize unbelievers in the last month? ( ) Yes ( ) No ( ) Has no religious belief.

Problem solving: ( ) makes decisions quickly ( ) takes time to make decisions ( ) often asks for help from family and friends

( ) cannot make decisions. Feeling anguished trying to come up with a decision? ( ) Yes ( ) No

\subsection{0- Coping}

What situations cause stress? Do you face stressful situations?

Have you sought help (medication/therapy) to cope with chronic stress/sadness? ( ) No ( ) Yes.

If so, which one (s)? Continued treatment (help)? () No ( ) Yes

\subsection{1- Safety and protection}

When sick, do you stick to treatment? ( ) No ( ) Yes. Self-medication? ( ) No ( ) Yes. Use of orthosis? ( ) No ( ) Yes. Gear Shift? ( ) No ( ) Yes.

If so, walking aids? Vulnerability for domestic accidents? ( ) No ( ) Yes; and for work accidents? ( ) No ( ) Yes.

Do you perform or have you ever performed prostate specific antigen (PSA) examination? ( ) No ( ) Yes. Date/Results:

Have you ever thought/attempted self-extermination? ( ) No ( ) Yes. Availability of firearm (s)? ( ) No ( ) Yes. History of violent behavior? ( ) No ( ) Yes

\subsection{2- Comfort}

Complaints of pain? ( ) No ( ) yes, place(s):

Type: ( ) tightening ( ) stab-like sensation ( ) other (s):

Pain intensity (VAS):

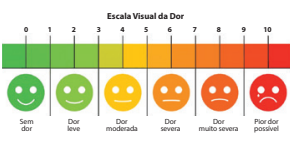


() To act, do for others (has a deficit in self-care and needs someone to do it)

( ) To support physically or emotionally (has a deficit in self-care and needs physical and emotional support to perform it)

( ) To provide an environment that promotes personal development (requires the environment to be appropriate)

( ) To teach (does not know how to perform self-care, needs someone to teach it)

( ) To guide (knows how to perform self-care, but needs someone to guide you to improve it)

\section{Nursing System}

User classification

() Fully compensatory

() Partially compensatory

() Support and education
Health deviation(s)

Nurse's impressions, observations or complications:

\section{DISCUSSION}

By elaborating and validating the data collection tool for nursing consultation with men in the context of $\mathrm{PHC}$, it contributes to the practice in primary care, in addition to scientificity. This tool represents an innovative tool to be employed in caring for the male population. This population is often neglected in this area of health care, serving as a guide in nursing consultation for the target audience.

All professional nurses participated in the study and have knowledge and practice in $\mathrm{PHC}$ regarding collective health attainment, including men. Most tool indicators have scientific evidence for their use. The involvement of professionals and researchers in the whole process was considered a favorable point for its establishment, as they assumed the condition of actors in this construction.

To identify empirical indicators, an integrative review of the scientific literature was performed. Validated empirical indicators, which portray the scientific vocabulary, the place of the institution and which are inserted in the service as integral part of NP establishment in the BHU of the municipality, were studied, according to the COFEN Resolution 358/2009(9).

The use of a tool to record and collect data in the first NP stage aimed to collect the comprehensive data of the male PHC user. The tool aimed to make possible the identification of vulnerabilities, problems that add harm to the client, potentials in the pursuit of health maintenance, allowing easy access to relevant data for the nurse.

Thus, this organized data will support the construction of a care plan, with the purpose of meeting the needs, preventing diseases and promoting interventions that reinforce wellbeing, health seeking and self-care behavior ${ }^{(17)}$. It should be taken into consideration that nursing consultation in $\mathrm{PHC}$ is an effective strategy, as it favors the approach and the construction of an interpersonal host relationship, in which nursing care management implies the recognition and fulfillment of care needs of the user-family binomial ${ }^{(18)}$. Therefore, it is evident that a tool for data collection must be easy to understand and complete (as in this study), otherwise, failures or omissions may be fulfilled ${ }^{(19-20)}$.

This study sought to contribute by proposing a meaningful tool for nursing care, with indicators that support the clinical decisions of $\mathrm{PHC}$ nurses and contribute to change establishment in their practice. Validation by nurse judges evidenced excellent value of overall CVI (0.88) and of the items (ranging between 0.82 and 1.00), thus, the tool includes information necessary for the assessment of the man served in PHC.

In the data collection phase of this research, the empirical indicators that identify the specific requirements of Orem's SCT were considered. These items have contributed to the initial actions of nursing care, as they allow the nurse to identify affected needs, with specific focus, facilitating the process of diagnostic reasoning. and, therefore, the denomination of nursing diagnoses, structured in a validated nomenclature for care for male PHC users.

Elimination and exchange, self-perception, roles and relationships, life principles (fundamental requirements), health-disease process, elimination and exchange, self-perception, coping (health deviations) and self-care deficit reached 1.0 CVI. In other words, $100 \%$ agreement between the judges, confirming the reliability of the tool built.

Among the imperative aspects of the language of a good tool are clarity and objectivity ${ }^{(21-22)}$. To avoid such problems, one of the aspects prioritized in this study was the use of clear and direct language.

Regarding the use of Orem's model, it has applicability in many contexts, since it provides the active participation of the user client in their self-care, improving health outcomes and therefore the person's well-being and quality of life ${ }^{(11-12)}$. Thus, the identification of universal requirements, developmental requirements, possible health deviations and self-care deficit, associated with the classification of the person within the nursing systems, will assist in the elaboration of nursing diagnoses and interventions related to self-control care teaching. This control involves the active participation of men in self-care, especially those involving changes in lifestyle and recognition of signs and symptoms that highlight health vulnerabilities ${ }^{(11)}$.

Therefore, from the assessment of preceptor and resident nurses, and adjustments made, it is considered that the tool included most of the data relevant to the assessment of self-care needs of men attending PHC. However, the professional must critically reflect in front of an individual and his family in the nursing consultation, adapting and redirecting the data collection. 
Literature points out that for the content analyzed by health sector tools, whether contemporary and relevant, it is essential for the researcher to insert himself in the target population context, knowing their specialties and needs $\mathrm{s}^{(21,23)}$.

The previous application of the tool in a small sample, characterizing the pretest, allowed to arrive at a preliminary version with choices more in tune with the target audience.

It was found that the average time for the application of the tool in the pilot sample was 30 minutes. This time exceeded the production capacity of consultations by health professionals, recommended by the Ministry of Health, since nurses need to perform three consultations per hour, with no distinction between new and follow-up consultations. However, there may be variations according to trade union conventions, collective bargaining in professional categories or adoption by the manager of specific policies. Therefore, nurses have an average of 20 minutes to perform nursing consultation ${ }^{(19)}$.

A study conducted in the PHC of England on the duration of consultations of more than one million visits, the average duration of nursing consultations was 9.24 minutes, with a minimum of four minutes and a maximum of 35 minutes. Authors stated that the duration of the nursing consultation is associated with the client's characteristics and the professional's level of practice. The increase in the patient's age is associated with the increased duration of the consultation. Nursing consultations were lower for women than for men. Smokers and former smokers had longer consultations than nonsmokers ${ }^{(24)}$. In this research, most of the men interviewed were smokers, which may have contributed to a longer time in data collection.

In another survey, a retrospective analysis of 100 million consultations in England, the average duration of nursing consultations was 10 minutes, ranging from 9 minutes to 72 minutes ${ }^{(25)}$.

It was observed that the duration of consultations in this study was exponentially reduced as the interviewing nurse became familiar. In order to adapt the application of the data collection tool, within the nursing consultation in the $\mathrm{PHC}$, training was conducted with the PHC nurses of the municipality study setting to familiarize the support guide and the tool constructed.

Choosing to establish Orem requirements within NANDA domains is considered to facilitate the definition of nursing diagnoses, continuing NP. This reasoning logic provided an opportunity for nurses to structure a data collection methodology more appropriate to the profession and to include indicators other than biophysical in approaching men during nursing consultations.

\section{Study limitations}

As a study limitation, what deserves to be highlighted is the lack of studies and information in the description of the data collection tools used in nursing consultations to adults, and based on Orem's SCT. Despite being focused on male PHC users, no publication was found, which made tool elaboration difficult.

The performance in a single professional and cultural context stands out, that is, in the PHC of a municipality from Minas Gerais. Therefore, it is suggested that the study be expanded to other Brazilian realities.

\section{Contributions to nursing, health or public policy}

It is believed that the use of the nursing research tool based on Orem's SCT for male PHC users will allow clientele's need assessment, enabling individualized intervention planning. However, it is believable that in the course of application in nursing consultations, other demands for adjustments appear, since there will be a larger sample. In this sense, it is suggested that large-scale application studies, that is, other Brazilian municipalities of this tool be carried out to polish it.

Studies in the context of PHC are believed to meet international national efforts to improve nurses' activities in this area. An Orem's SCT-based nursing research tool elaboration for a specific clientele, in this case male PHC users, is the first step for planning and establishing individualized and context-appropriate actions.

\section{CONCLUSIONS}

Tool construction was based on Orem's philosophical theoretical framework, organized according to Theory Requirements and subdivided into NANDA domain titles, which allows a closer correlation with nursing diagnoses.

The tool was established in the nursing consultation of men served at a BHU with Family Health team in Minas Gerais, having an excellent assessment. There is a need for application in other settings to improve the tool, mainly due to this population segment for the use of PHC as a gateway to SUS. One possible strategy would be to partner with these men's employer sectors, so that workplaces can be health promotion and disease prevention settings when addressing issues relevant to self-care.

\section{REFERENCES}

1. Fracolli LA, Gomes MFP, Nabão FRZ, Santos MS, Cappellini VK, Almeida ACC. Instrumentos de avaliação da Atenção Primária à Saúde: revisão de literatura e metassíntese. Ciênc Saúde Colet [Internet]. 2014 [cited 2018 Dec 02];19(12):4851-60. Available from: http://www.scielo.br/ pdf/csc/v19n12/pt_1413-8123-csc-19-12-04851.pdf

2. Dantas AEA, Santos AEM, Nóbrega JM, Araújo RRG, Oliveira Filho VF, Salomão MAAO. Perfil de homens a partir dos 40 anos atendidos no Programa Saúde do Homem. Rev Ciênc Saúde Nova Esperança [Internet]. 2015 [cited 2018 Dec 03];13(1):21-33. Available from: http://www. facene.com.br/wp-content/uploads/2010/11/Perfil-de-homens-PRONTO.pdf

3. Oliveira PP, Santos WJ, Viegas SMF, EAA Silveira, Rodrigues AB. Experience of men in the context of Primary Health Care. Invest Educ Enferm [Internet]. 2015 [cited 2018 Dec 02];33(2);227-36. Available from: http://www.scielo.org.co/pdf/iee/v33n2/v33n2a05.pdf

4. Ministério da Saúde (BR). Secretaria de atenção à Saúde. Departamento de Ações Programáticas Estratégicas. Política Nacional de Atenção Integral à Saúde do Homem: princípios e diretrizes [Internet]. Brasília (DF): Ministério da Saúde; 2009 [cited 2018 Dec 03]. Available from: http://portalarquivos2.saude.gov.br/images/pdf/2014/maio/21/CNSH-DOC-PNAISH---Principios-e-Diretrizes.pdf 
5. Silva AN, Silva SA, Silva ARV, Araújo TME, Rebouças CBA, Nogueira LT. Primary care assessment from a male population perspective. Rev Bras Enferm [Internet]. 2018 [cited 2018 Nov 28];71(2):236-43. Available from: http://dx.doi.org/10.1590/0034-7167-2016-0651

6. Abrahão AL, Amaral IT. Nursing consultation in Family Health Strategy, increasing the recognition of the distinct forms of action: an integrative review. Rev Pesqui Cuid Fundam [Internet]. 2017 [cited 2018 Nov 28];9(4):899-906. Available from: http://www.seer.unirio.br/ index.php/cuidadofundamental/article/view/4539/pdf_1

7. Benedet SA, Padilha MI, Gelbke FL, Bellaguarda MLR. The model professionalism in the implementation of the Nursing Process (1979-2004). Rev Bras Enferm [Internet]. 2018[cited 2018 Nov 28]; 71(4):1907-14. Available from: http://dx.doi.org/10.1590/0034-7167-2017-0226

8. Mutshatshi TE, Mamogobo PM, Mothiba TM. Experiences of nurses during the implementation of the nursing process in selected public hospitals in the Vhembe District, Limpopo Province, South Africa. African J Phys Health Educ Recreat Dance [Internet]. 2015 [cited 2017 May 12];1(2):445-55. Available from: https://journals.co.za/content/ajpherd/21/sup-1/EJC183622

9. Conselho Federal de Enfermagem-Cofen. Resolução Cofen n 358, de 15 de outubro de 2009: Dispõe sobre a Sistematização da Assistência de Enfermagem e a implementação do Processo de Enfermagem em ambientes, públicos ou privados, em que ocorre o cuidado profissional de Enfermagem, e dá outras providências. Diário Oficial da União [Internet]. 2009 Oct 23[cited 2016 May 22]; 1:179. Available from: http://www.cofen.gov.br/resoluo-cofen-3582009_4384.html

10. Orem DE. Nursing concepts of practice. 6th. Ed. St. Louis: Mosbyi; 2001.

11. Hernández YN, Pacheco JAC, Larreynaga MR. La teoría Déficit de autocuidado: Dorothea Elizabeth Orem. Sancti Spíritus [Internet]. 2017 [cited 2018 Dec 02];19(3):89-100. Available from: http://www.revgmespirituana.sld.cu/index.php/gme/article/view/1129

12. Costa DO, Araújo FA, Xavier ASG, Araújo LS, Silva UB, Santos EA, et al. Self-care of men with priapism and sickle cell disease. Rev Bras Enferm [Internet]. 2018 [cited 2018 Dec 02];71(5):2418-24. Available from: http://dx.doi.org/10.1590/0034-7167-2017-0464

13. Conselho Nacional de Saúde (BR). Resolução n 466, de 12 de dezembro de 2012 [Internet]. Brasília (DF), 2012 [cited 2018 Nov 30 ]. Available from: http://conselho.saude.gov.br/resolucoes/2012/Reso466.pdf

14. Melo DM, Barbosa AJG, Neri AL. Miniexame do Estado Mental: evidências de validade baseadas na estrutura interna. Aval psicol [Internet]. 2017 [cited 2019 Jan 09];16(2):161-68. Available from: http://pepsic.bvsalud.org/pdf/avp/v16n2/v16n2a07.pdf

15. Canhota C. Qual a importância do estudo piloto. In: Associação Portuguesa dos Médicos de Clínica Geral. Investigação passo a passo: perguntas e respostas para investigação clínica. Lisboa: APMCG; 2008 [cited 2018 Nov 30]; p.69-72. Available from: http://www.apmgf.pt/ ficheiros/Investiga\%C3\%A7\%C3\%A30\%20Passo\%20a\%20Passo.pdf

16. Medeiros RKS, Ferreira Jr MA, Pinto DPSP, Vitor AF, Santos VEP, Barichello E. Modelo de validação de conteúdo de Pasquali nas pesquisas em Enfermagem. Rev Enferm Ref [Internet]. 2015 [cited 2018 Nov 30];4(4):127-35. Available from: http://www.scielo.mec.pt/pdf/ref/vserlVn4/ serlVn4a14.pdf

17. Sousa Neto VL, Silva RAR, Silva CC, Negreiros RV, Rocha CCT, Nóbrega, MML. Proposal of nursing care plan in people hospitalized with AIDS. Rev Esc Enferm USP [Internet]. 2017 [cited 2018 Dec 04];51: e03204. Available from: http://dx.doi.org/10.1590/S1980-220X2016027203204

18. Herdman TH, Kamitsuru S. Diagnósticos de enfermagem da NANDA: definições e classificação 2018-2020. Porto Alegre: Artmed; 2018.

19. Dantas CN, Santos VEP, Tourinho FSV. Nursing consultation as a technology for care in light of the thoughts of Bacon and Galimberti. Texto Contexto Enferm [Internet]. 2016 [cited 2018 Dec 04]; 25(1):e2800014. Available from: http://www.scielo.br/pdf/tce/v25n1/0104-0707tce-25-01-2800014.pdf

20. Rodrigues AB, Cunha GH, Aquino CBQ, Rocha SR, Mendes CRS, Firmeza MA, et al. Head and neck cancer: validation of a data collection instrument. Rev Bras Enferm [Internet]. 2018 [cited 2018 Dec 04];71(4):1899-906. Available from: http://dx.doi. org/10.1590/0034-7167-2017-0227

21. Leite SS, Áfio ACE, Carvalho LV, Silva JM, Almeida PC, Pagliuca LMF. Construction and validation of an Educational Content Validation Instrument in Health. Rev Bras Enferm [Internet]. 2018 [cited 2019 Jan 10];71(suppl 4):1635-41. [Thematic Issue: Education and teaching in Nursing] Available from: http://dx.doi.org/10.1590/0034-7167-2017-0648

22. Marques DKA, Silva KL, Nóbrega MML. Hospitalized school children: proposition of a data collection instrument in light of Horta's theory. Rev Gaúcha Enferm [Internet]. 2016 [cited 2018 Dec 04];37(spe):e2016-0038. Available from: http://www.scielo.br/pdf/rgenf/v37nspe/ en_0102-6933-rgenf-1983-14472016esp2016-0038.pdf

23. Teston EF, Sales CA, Marcon SS. Perspectives of individuals with diabetes on selfcare: contributions for assistance. Esc Anna Nery [Internet]. 2017 [cited 2018 Dec 04];21(2):e20170043. Available from: http://www.scielo.br/pdf/ean/v21n2/1414-8145-ean-21-02-e20170043.pdf

24. Stevens S, Bankhead C, Mukhtar T, Perera-Salazar R, Holt TA, Salisbury C, et al. Patient-level and practice-level factors associated with consultation duration: a cross-sectional analysis of over one million consultations in English primary care. BMJ Open [Internet]. 2017;7(11):e018261. Available from: https://bmjopen.bmj.com/content/7/11/e018261.long

25. Hobbs FDR, Bankhead C, Mukhtar T, et al. Clinical workload in UK primary care: a retrospective analysis of 100 million consultations in England, 2007-14. Lancet [Internet]. 2016 [cited 2018 Dec 04]; 387:2323-30. Available from: https://www.ncbi.nlm.nih.gov/pmc/articles/ PMC4899422/ 